\title{
FUZZY COGNITIVE MAPS AND THEIR APPLICATION IN THE ECONOMIC SCIENCES
}

\section{Iwona Bąk}

West Pomeranian University of Technology, Szczecin, Poland

e-mail: iwona.bak@zut.edu.pl

ORCID: 0000-0001-8959-7269

\section{Katarzyna Cheba}

West Pomeranian University of Technology, Szczecin, Poland e-mail: katarzyna.cheba@zut.edu.pl

ORCID: 0000-0001-8753-77641

\section{(C) 2020 Iwona Bąk, Katarzyna Cheba}

This work is licensed under the Creative Commons Attribution-ShareAlike 4.0 International License. To view a copy of this license, visit http://creativecommons.org/licenses/by-sa/4.0/

Quote as: Bąk, I., and Cheba, K. (2020). Fuzzy cognitive maps and their application in the economic sciences. Econometrics. Ekonometria. Advances in Applied Data Analysis, 24(3).

DOI: $10.15611 /$ eada.2020.3.02

JEL Classification: C65, O11, P36

\begin{abstract}
The main purpose of the paper is an expert assessment of the relationship existing between selected indicators carried out using a relatively new tool in economic sciences: Fuzzy Cognitive Maps. The effect of its application is a graphical presentation of the relationship between the factors identified as the key ones. In the paper 23 indicators, describing four selected goals in the Strategy for Sustainable Development, 2030 Agenda were selected. It is assumed that the sustainable development goals should be related but according to the experts opinion this only applies to some indicators. This kind of relationships can be certainly identified in the case of the goals describing social and economic development, but often also economic and environmental development. However, the research results presented in the paper do not always confirm the existence of connections between individual indicators selected for the description of the goals of sustainable development. The paper tries to explain this problem.
\end{abstract}

Keywords: cognitive maps, CM, fuzzy cognitive maps, FCM, relationships, graphical presentation.

\section{Introduction}

Fuzzy Cognitive Maps (FCM) is a research tool used to study cause-and-effect links between factors determining the development (the lack of development) of the phenomenon under investigation (Godlewska-Majkowska, 2014). The main effect of its application is a graphical presentation of the relationship between the factors 
identified as the key ones. This a tool that was created as a modification of cognitive maps (CM), commonly referred to as association maps. CM is a solution that was first used in the humanities by R. Axelrod in 1976. The basis for creating a cognitive map is cause-and-effect dependencies (associations) of a complex nature, presented in the form of a simple graph consisting of edges and vertices. The vertices in this model represent the factors associated with the analysed problem, and the edges describe the relationships (positive or negative impact) between them. The direction of the arrows and the indicator accompanying them show the dependency type and its strength (usually between -1 and 1).

However, there are some limitations in presenting the relationships between factors in this way, mainly due to the possibility of presenting only two extreme interactions between factors. The solution to this problem is the fuzzy cognitive maps introduced by B. Kosko in 1986 (Jastriebow, Gad, and Słoń, 2010), which also takes into account less intensity (strength) relationships. As in econometric models, the impact of a set of explanatory factors on the explanatory variable is examined here, looking primarily at the relationship between the conditions of the phenomenon under examination. This perspective enables the researchers to obtain an answer to the question as to which of the conditions (in the paper referred to as factors) have the most significant impact on the studied phenomenon, taking into account not only direct but also indirect impacts.

This solution is used as an auxiliary at the stage of structuring the research problem. It answers questions about how different types of factors connect. The density of the map that illustrates the number of links existing between these factors can also be determined. Despite some quantitative characteristics that the authors receive as additional information about the designated map (map density, the number of transmitting and receiving factors), it is a qualitative tool based most often on expert assessments of the direction and strength of the relationship between the factors considered. In this respect, some similarities can be found between $\mathrm{CM}$ and FCM and the multi-criteria methods of hierarchical analysis of decision-making processes, such as analytical hierarchy methods (e.g. Analytic Hierarchic Process, AHP; Analytic Network Process (ANP), or verbal methods (e.g. ZAPROS), (Trzaskalik, 2014). The main similarity concerns the use of verbal assessments, e.g. to compare different types of decision-making options. Expert studies (individual or group) are also one of the stages in the creation of cognitive maps, which are used at the stage of identifying the most important factors influencing the development of the phenomenon under investigation. The growing popularity of FCM and the increasing use of various scientific disciplines and research areas have also contributed to the increased interest in this tool in the field of economics and management. Examples of such applications are presented in the next part of the work.

The tool was also used to study the relationship between the factors determining the development of EU countries in accordance with the principles of sustainable development. Relocation is one of the elements taken into account when creating 
lists of the factors used by the European Commission to measure progress towards further sustainable development strategies. Until 2016 the relationship between the factors was considered hierarchically. Individual indicators were assigned to successive levels of the pyramid, ranging from the so-called explanatory indicators through operational indicators to the highest level of the pyramid described by the so-called headline indicators. As demonstrated in Szopik-Depczyńska et al. (2018), despite the hierarchical layout of the indicators considered, achieving a high level of development e.g. at operational level, did not guarantee a similar or higher result at the highest level. In the latest Strategy for Sustainable Development. 2030 Agenda, the indicators selected by the EC were assigned to 17 goals. In addition, within each of them, the relationships with selected indicators of other goals describing other strategy's goals are examined. Goal 1, No poverty, is described by 8 indicators, and also its relationships with indicators selected from the goals were studied: $3,6,7$, 11. Similar links can be observed for other goals. The primary purpose of presenting sustainable development goals (SDGs) in this way is to emphasize the relationships that connect them. These relationships are treated similarly by the authors of this work.

Therefore the main purpose of the paper is an expert assessment of the relationship between selected sustainability indicators carried out using a relatively new tool in economic sciences: Fuzzy Cognitive Maps.

The paper is divided into two parts. The first presents the theoretical basis for measuring the relationship between selected indicators applied by the EC to monitor the progress in the implementation of the last Sustainable Development Strategy. The second presents the results of measuring these relationships considered in relation to European Union countries based on Eurostat data, Where the FCM is used to present the relationships between these indicators. An essential part of the work is the conclusions and information about further research directions.

\section{Examples of FCM applications in economic research}

A cognitive map is a universal tool that uses knowledge and experience to learn and analyse phenomena occurring in the world around us. In the subject literature there are numerous examples of the use of this tool to diagnose various phenomena. These studies point out that the following two approaches are most commonly used to build cognitive maps (Słoń and Yastrebov, 2011):

- econometric, which models mathematical relationships,

- expert procedure, which mainly uses the Delphi method and relatively simple calculation procedures.

Piotrowska (2011) shows the use of cognitive maps in intelligent decision-making assistance systems. An application was developed and presented to implement sharp cognitive maps, implement a gradient learning process, and observe dynamic system changes. The program was discussed using the example of a road transport decision- 
-making assistance system and a system to support the integration of transport policy into ecological policy.

The use of a cognitive map as an instrument to support the design of an integrated territorial tourism product is presented by Godlewska-Majkowska (2014), which proved that the cognitive map allows supporting the creation of new, integrated tourist products, as well as the modification of existing ones. Its application can take into account the high instability of socio-economic phenomena.

Jastriebow et al. (2010) presented a specific approach to analyzing the work of poorly structured systems, using a cognitive map to describe the relationship between the key factors. The uncertainty resulting from the ignorance of the object's exact structure and inaccuracy in the reading of symptoms was minimized by using fuzzy inference. A simulation analysis of the dynamic diagnostic monitoring of the sample system is presented.

Skład (2018) proposed the method of fuzzy cognitive maps as a tool supporting the improvement of the effectiveness of OSH management systems in enterprises. This method assumes the development of a system model in the form of a set of elements that make up the system and their mutual influences. Using a mathematical formula, one can determine the values of individual model elements and then forecast their future values.

The potential usefulness of fuzzy cognitive mapping in educational organization settings is presented in the paper by Cole and Persichitte (2000). Two specific educational applications of FCMs are explored in detail, and recommendations are included for further investigations within educational contexts.

Kokkinos, Lakioti, Papageorgiu, Moustakas, and Karayannis (2018) suggested using cognitive maps in order to analyze the socio-economic implications and to overcome multiple uncertainties occurring in sustainable WBF (Sustainable Waste Biorefinery Facilities) development and implementation.

In Stylios and Goumpos (1999), the authors presented cognitive maps as a useful modelling method that can be used to control complex systems in, e.g. the chemical, cement and oil industries.

Other examples of using this tool to diagnose various types of phenomena include:

- modelling (Tan and Ozesmi, 2006; Salmeron, 2009; Papageorgiou, Markinos, and Gemtos, 2009),

- knowledge management (Taber, 1991; Wei, Lu, and Yanchun, 2008),

- political and social issues (Andreou, Mateou, and Zombanakis, 2003, 2005),

- engineering and technology management (Lee and Han, 2000; Salmeron, 2009),

- agriculture and ecological modelling (Papageorgiou, Markinos, and Gemtos, 2009),

- management (Isaac, Dawoe, and Sieciechowicz, 2009),

- forecasting (Furfaro Kargel, Lunine, Fink, and Bishop, 2010; Song, Miao, Roel, Shen, and Catthoor, 2010), 
- supporting medical decisions and classification tasks (Kannappan, Tamilarasi, and Papageorgiou, 2011; Papageorgiou, Markinos, and Gentos, 2008),

- sustainable financial systems (Papageorgiou, 2012; Zioło, Filipiak, Bąk, and Cheba, 2019).

\section{Research procedure}

The process of building cognitive maps includes several stages, some of which are carried out irrespective of the adopted approach, namely: a) establishing a list of initial criteria explaining the phenomenon under study, b) selecting criteria of the most significant importance for the target model of the dependency research being created, c) development of the correlation matrix between the considered criteria (Godlewska-Majkowska, 2014). As part of the first stage, an interview questionnaire for expert research was prepared based on the collected information. In the second stage of the study, experts with knowledge in the analysed areas were selected. Their opinions were used to identify cause-effect relationships and determine their intensity and direction. As part of the third stage, the list of initially identified factors was ordered, and then the established cause-effect relationships between them verified. The result was the first versions of maps on which the strength of the influence of each of the analysed developmental conditions was measured, first on a verbal (descriptive) scale, and then it transformed into a numerical scale. The final result of the adopted procedure was a cognitive matrix presenting the averaged assessments of the intensity of the relationships between the factors of significant importance for the analysed area and a map of cognitive factors.

Another point of the analysis was the recognition of the type of factors presented on the map. This type of diagnosis makes it easier to understand the map structure. Three types of factors can be presented on the map: factors acting as transmitters $(T)$, which initiate relations with others (forcing functions), factors acting as receivers $(R)$, to which the influence of forcing factors are directed (utility factors). It was also possible to identify an independent set, i.e. a set of vertices between which there is no relationship.

In the next point the complexity of the map was calculated. The complexity may be demonstrated by the total number of receiver factors (utility factors). If the map takes into account many factors and the relations between them, tantamount to the presence of many factors acting as a receiver. Too many factors acting as a transmitter will prove too much 'smoothness' of the map (no relationship between the factors), and thus errors in identifying the factors describing the problem under study (Ozesmi and Ozesmi, 2004). The relationships between the factors acting as receivers and transmitters were used to compare the map's complexity based on the following formula:

the complexity of the map $=\frac{R}{T}$. 
In more complex maps this coefficient will be higher due to the large number of relations between the factors.

It is also possible to calculate the density of the map. In the analysis of the obtained results, the following features of the drawn maps were used: the density and type of variables presented on the map. The density (or clustering coefficient) of the fuzzy cognitive map $(D)$ is the connectivity index that shows how the analysed developmental conditions on the map are connected (Ozesmi and Ozesmi, 2004). The following formula was used to determine the grouping factor:

$$
D=\frac{C}{N(N-1)}
$$

or

$$
D=\frac{C}{N^{2}} .
$$

According to the first of these formulas, the number of existing connections on the map is divided by the maximum possible number of connections that may occur between the analyzed factors (Hage and Harary, 1983). The second formula is used in a situation where the individual criteria interact only in a causal manner. If the map density is high, then a large number of cause-effect or causal relationships between the analyzed factors are observed.

To assess the quality of replications on the map the hierarchy index $(h)$ proposed by MacDonald (1983) can also be used to assess:

$$
h=\frac{12}{(N-1) N(N+1)} \sum_{i}\left[\frac{\operatorname{od}\left(v_{i}\right)-\left(\operatorname{od}\left(v_{i}\right)\right)^{2}}{N}\right]^{2},
$$

where: $\operatorname{od}\left(v_{i}\right)$ is outdegree - is the row sum of absolute values of a variable in the adjacency matrix calculated as follows:

$$
o d\left(v_{i}\right)=\sum_{k=1}^{N} \bar{a}_{j k}
$$

and $N$ is the total number of variables.

The application of the proposed solution allowed the authors to predict possible changes in the studied phenomenon. For this purpose, a broad spectrum of available information, as well as the experts' knowledge and experience were used. The main advantage of the created maps was the possibility of using them both for static and dynamic assessments. They can also be used in the case of assessing the possibilities and directions of the development of new phenomena not yet sufficiently described in the literature or studies in the field of economic practice. 


\section{The applications of FCM to structure the relationships between selected sustainable development indicators}

In the study whose results are presented in this paper, the expert approach was used to build a fuzzy cognitive map. The basis for the selection of the most significant factors for the target model of relationships was the list of selected input factors used by the European Commission to monitor progress in the implementation of the latest Sustainable Development Strategy of EU countries. The original list included indicators describing: social development, Goal 1. No poverty; economic development, Goal 8. Decent work and economic growth; environmental development, Goal 13. Climate action, and institutional and political development, Goal 17. Partnerships for the goals. In total, 23 indicators were analysed (Table 1).

Table 1. List of indicators

\begin{tabular}{|c|c|}
\hline Goal & List of indicators \\
\hline 1 & 2 \\
\hline \multirow{6}{*}{$\begin{array}{l}\text { Goal } 1 . \\
\text { No poverty }\end{array}$} & SDG01_10: people at risk of poverty or social exclusion, $\%$ \\
\hline & SDG01_20: people at risk of income poverty after social transfers, $\%$ \\
\hline & SDG01_30: severely materially deprived people, $\%$ \\
\hline & $\begin{array}{l}\text { SDG01_40: people living in households with very low work intensity, } \% \text { of } \\
\text { population less than } 60\end{array}$ \\
\hline & SDG01_41: in work at-risk-of-poverty rate, $\%$ of employed persons aged 18 or over \\
\hline & $\begin{array}{l}\text { SDG01_60: population living in a dwelling with a leaking roof, damp walls, floors or } \\
\text { foundations, or rot in window frames or floor, } \% \text { of population }\end{array}$ \\
\hline \multirow{6}{*}{$\begin{array}{l}\text { Goal } 8 . \\
\text { Decent } \\
\text { work and } \\
\text { economic } \\
\text { growth }\end{array}$} & SDG08_10: real GDP per capita, EUR per capita \\
\hline & SDG08_11: investment share of GDP, \% of GDP \\
\hline & $\begin{array}{l}\text { SDG08_20: young people neither in employment nor in education and training, } \% \\
\text { of population aged } 15 \text { to } 29\end{array}$ \\
\hline & SDG 08_30: employment rate, \% of population aged 20 to 64 \\
\hline & SDG08_40: long-term unemployment rate, $\%$ of active population \\
\hline & SDG08_60: people killed in accidents at work, number per 100000 employees \\
\hline \multirow{6}{*}{$\begin{array}{l}\text { Goal } 13 . \\
\text { Climate } \\
\text { action }\end{array}$} & SDG13_10: greenhouse gas emissions, in $\mathrm{CO}_{2}$ equivalent \\
\hline & SDG13_20: greenhouse gas emissions intensity of energy consumption, index $2000=100$ \\
\hline & SDG13_30: mean near-surface temperature deviation, degree Celsius \\
\hline & $\begin{array}{l}\text { SDG13_40: climate related economic losses, million EUR and EUR per capita } \\
\text { (current prices) }\end{array}$ \\
\hline & $\begin{array}{l}\text { SDG13_50: contribution to the international } 100 \text { bn USD commitment on climate } \\
\text { related expending, million EUR (current prices) }\end{array}$ \\
\hline & $\begin{array}{l}\text { SDG13_60: population covered by the Covenant of Mayors for Climate \& Energy } \\
\text { signatories, \% of total population }\end{array}$ \\
\hline
\end{tabular}




\begin{tabular}{|c|l|}
\hline 1 & \multicolumn{1}{|c|}{2} \\
\hline $\begin{array}{l}\text { Goal 17. } \\
\text { Partnerships } \\
\text { for the goals }\end{array}$ & $\begin{array}{l}\text { SDG17_10: official development assistance as share of gross national income, \% of } \\
\text { gross national income }\end{array}$ \\
\cline { 2 - 2 } & $\begin{array}{l}\text { SDG17_20: EU financing to developing countries by financing source, million EUR } \\
\text { (current prices) }\end{array}$ \\
\cline { 2 - 2 } & $\begin{array}{l}\text { SDG17_30: EU imports from developing countries by country income groups, million } \\
\text { EUR }\end{array}$ \\
\cline { 2 - 3 } & SDG17_40: general government gross debt, \% of GDP \\
\cline { 2 - 3 } & SDG17_50: share of environmental taxes in total tax revenue, \% \\
\hline
\end{tabular}

Source: own elaboration based on Eurostat data.

The task of the experts participating in the study was to determine both the strength of the impact of selected indicators on the further development of countries around the world under the concept of sustainable development, as well as to indicate the direction of this impact (positive versus negative impact). The experts could make their assessments on a 5-point Likert scale, where 1 meant the smallest impact, but positive on the studied phenomenon, and 5 - the most significant impact, also positive. Conversely, the criterion assigned, for example, the value of -1 had the smallest negative impact on the further development opportunities of the countries within the analysed development concepts, and $-5-$ also the largest negative one. A detailed breakdown of the ratings that can be given by the experts and their recoding on a scale from -1 to 1 used in creating fuzzy cognitive maps are presented in Table 2.

In the next stage of the study the matrix showing the relationships between the selected indicators was determined. To analyse a cognitive map, the number of indicators $(N)$ and the number of connections $(C)$ in the map was counted. The vector of $C$-objects values and the matrix of influences $W$ taking place between objects in the fuzzy cognitive map can be presented as follows.

When analysing the indicators describing individual goals and their possible combinations, several regularities can be noticed. The indicators describing the first goal included in the social dimension should be strongly related to the indicators describing the first goal included in the economic dimension (Figure 1). The indicators describing Goal 8 will, in most cases, improve the results in terms of Goal 1, i.e. increase the value of indicators such as SDG08_10, real GDP per capita, SDG08_11, investment share of GDP, and SDG 08_30, employment rate, should, according to experts, cause a decline in the value of all Goal 1 indicators. On the cognitive map showing the relationships in this area, these connections are visualized in the form of a dashed line. The arrowhead showing these relationships points towards the indicators from Goal 1. 
Table 2. Distribution of ratings awarded by the experts

\begin{tabular}{|c|l|c|}
\hline Strength connection by experts & $\begin{array}{c}\text { Sign and strength of relationship } \\
\text { (linguistic weight) }\end{array}$ & Interpreted crisp weight \\
\hline-5 & negatively very strong & -1 \\
\hline-4 & negatively strong & $-0,8$ \\
\hline-3 & negatively medium & $-0,6$ \\
\hline-2 & negatively weak & $-0,4$ \\
\hline-1 & negatively very weak & $-0,2$ \\
\hline 0 & zero & 0 \\
\hline 1 & positively very weak & 0,2 \\
\hline 2 & positively weak & 0,4 \\
\hline 3 & positively medium & 0,6 \\
\hline 4 & positively strong & 0,8 \\
\hline 5 & positively very strong & 1 \\
\hline
\end{tabular}

Source: own elaboration based on (Ozesmi and Ozesmi, 2004).

$$
C=\left[\begin{array}{l}
C_{1} \\
C_{2} \\
C_{3} \\
C_{4} \\
C_{5}
\end{array}\right] \quad \text { (1) } W=\left[\begin{array}{ccccc}
0 & -W_{12} & -W_{13} & -W_{14} & 0 \\
-W_{21} & 0 & 0 & 0 & 0 \\
-W_{31} & 0 & 0 & 0 & 0 \\
0 & -W_{42} & 0 & 0 & 0 \\
W_{51} & 0 & 0 & 0 & 0
\end{array}\right]
$$

However, in the case of SDG08_20, young people neither in employment nor in education and training, SDG08_40, long-term unemployment rate, and SDG08_60, people killed in accidents at work, these relations will run in the opposite direction. An increase in the value of these indicators will also increase the values of indicators from Goal 1, with the indicator SDG08_40 having the most decisive impact on the indicators from Goal 1. This type of relationship is marked on the map with a continuous line.

The experts participating in the study also pointed to the connections between the indicators describing Goal 8 and Goal 13 (Figure 2). This connection applies, for example, to indicators SDG08_10, real GDP per capita, SDG08_11, investment share of GDP, SDG13_10, greenhouse gas emissions, and SDG13_20, greenhouse gas emissions intensity of energy consumption. According to the experts, the values of the above-mentioned indicators describing the environmental dimension should decrease along with the growth of the indicators describing the economic dimension.

On the other hand, the positive relationships concern some of the indicators describing Goals 8 and 17 (Figure 3). An increase in GDP per capita should increase the value of SDG17_10, official development assistance as a share of gross national income, SDG17_20, EU financing to developing countries by financing source, and SDG17_30, EU imports from developing countries by country income groups and the decline in the value of SDG17_40, general government gross debt. 


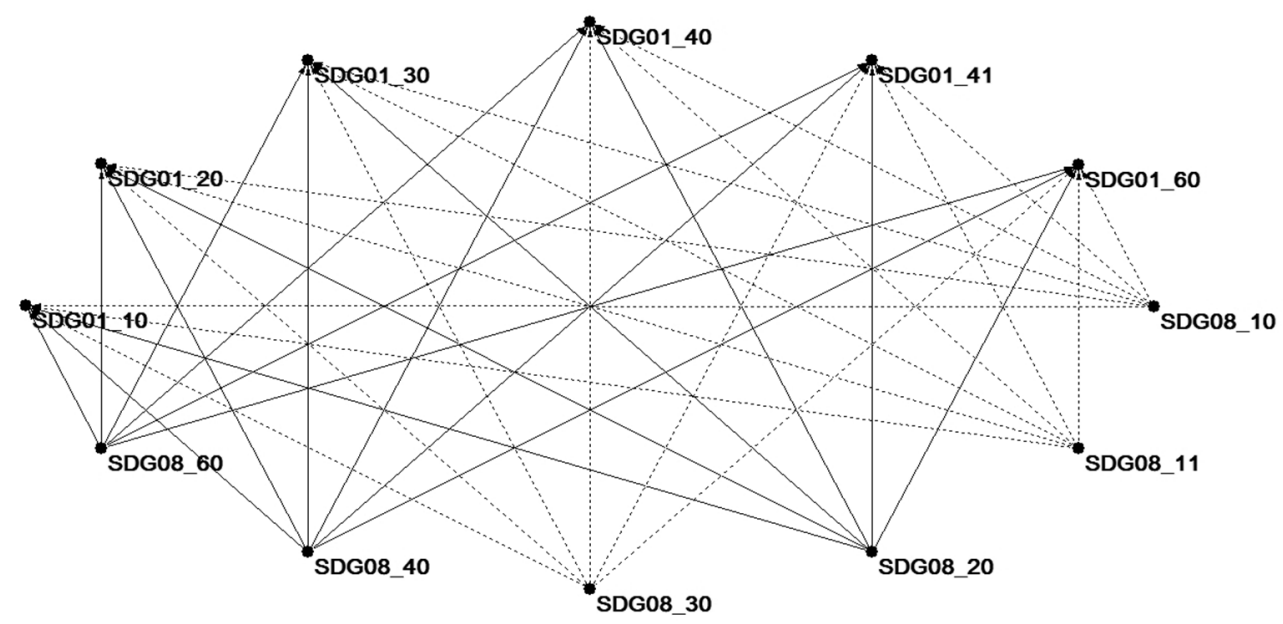

Fig. 1. The FCM for goals 1 and 8

Source: own elaboration.

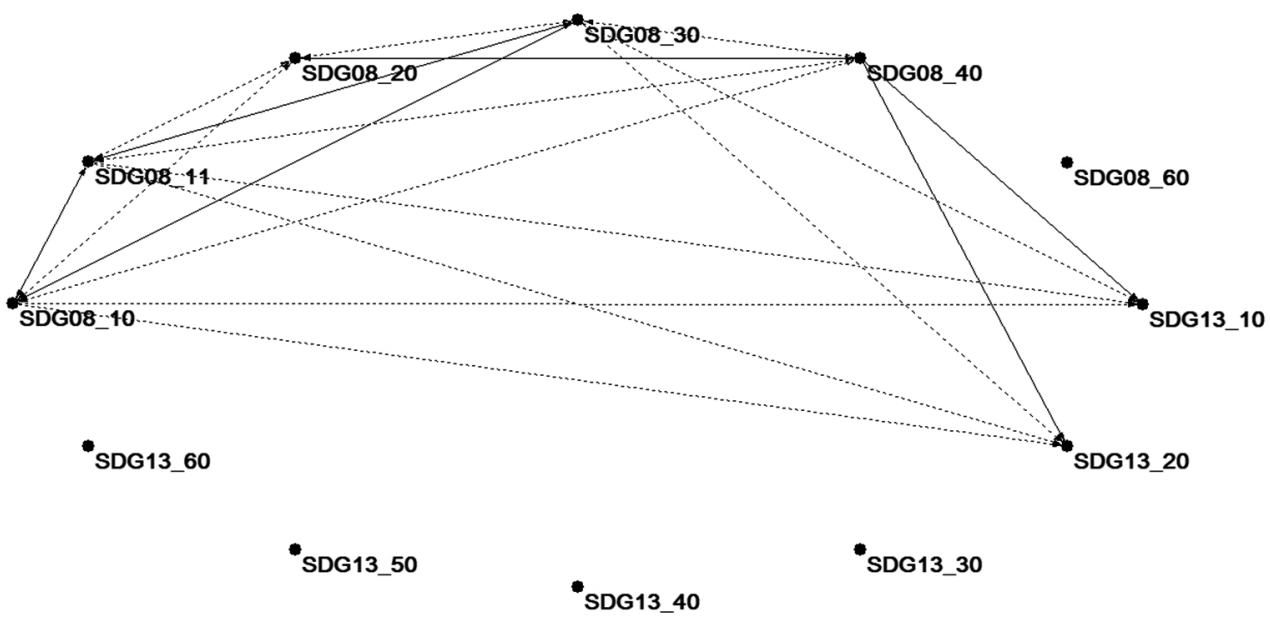

Fig. 2. The FCM for goals 8 and 13

Source: own elaboration.

In turn, the relations with the SDG17_50 indicator are interesting: the share of environmental taxes in total tax revenue. According to the definition by Eurostat, environmental taxes are defined as taxes whose tax base consists of a physical unit (or similar) of some material that has a negative, verified, and specific impact on the environment. Despite the established definition, the methods of their determination 


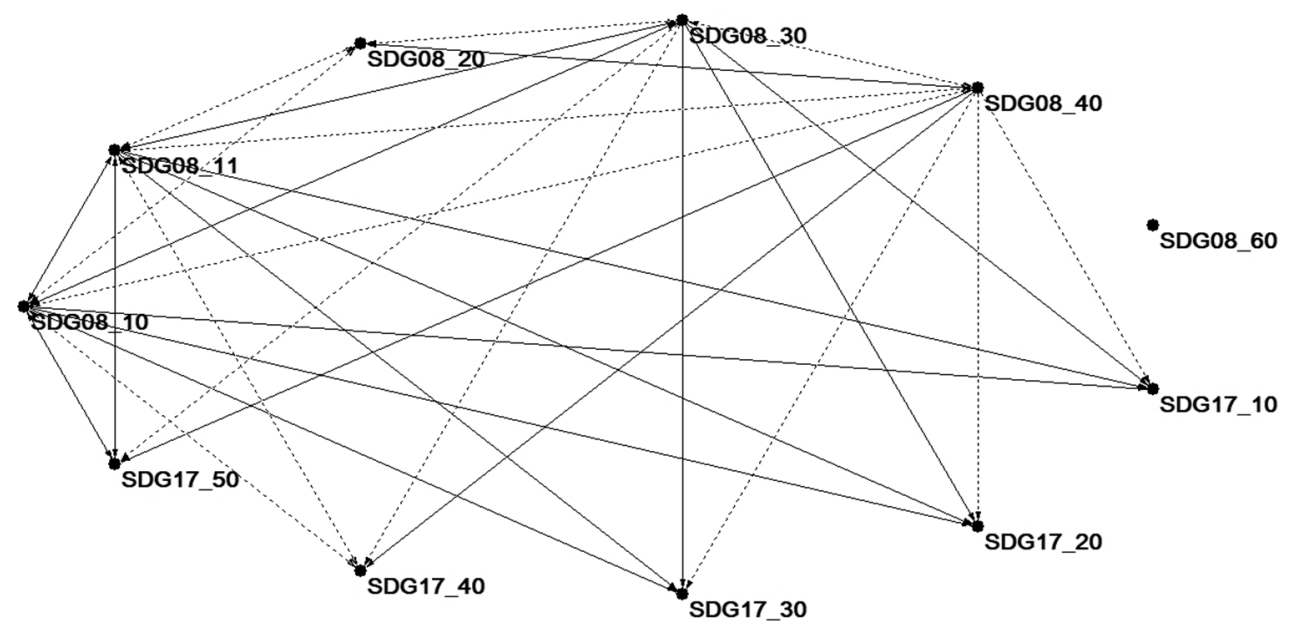

Fig. 3. The FCM for goals 8 and 17

Source: own elaboration.

in the EU countries differ. The tax policy pursued in some European countries (the Netherlands, Great Britain, and the Scandinavian countries) indicates that taxes can be effective and, in a way, a self-financing instrument of environmental protection. The intensive development of tax legislation, penalizing the consumption of fossil fuels and other energy sources, is related to the functioning of the environmental tax reform (ERP) especially strongly promoted along with the development of the tendency to harmonize the tax systems of the European Union Member States. In Denmark, the revenue from the taxation of households and enterprises from $\mathrm{CO}_{2}$ emissions mainly go back to the business sector in an indirect form (the reduction of employers' social security contributions) and directly in the form of subsidies for investment in green energy sources and improvement of working conditions in small enterprises. On the other hand, many green taxes have been introduced in Germany, penalizing, e.g. gas, heating oil, and other heating fuels, while reducing social security contributions for employers and employees. This policy has a decisive impact on the way of visualization of connections between this indicator and, e.g. the indicators describing Goal 13 which, depending on the definition adopted by a given country and the way of using environmental taxes, may positively influence e.g. GDP growth per capita or be a negative effect of this growth.

The connections between the analysed indicators indicated by the experts allowed for the preparation of a comprehensive cognitive map collectively presenting all the identified relationships (Figure 4) and, additionally, the impact of the analysed indicators on the overall assessment of the level of implementation of the sustainable development strategy (SD). For this purpose, the FCMapper_bugfix_27.1.2016 software was used in the research. 


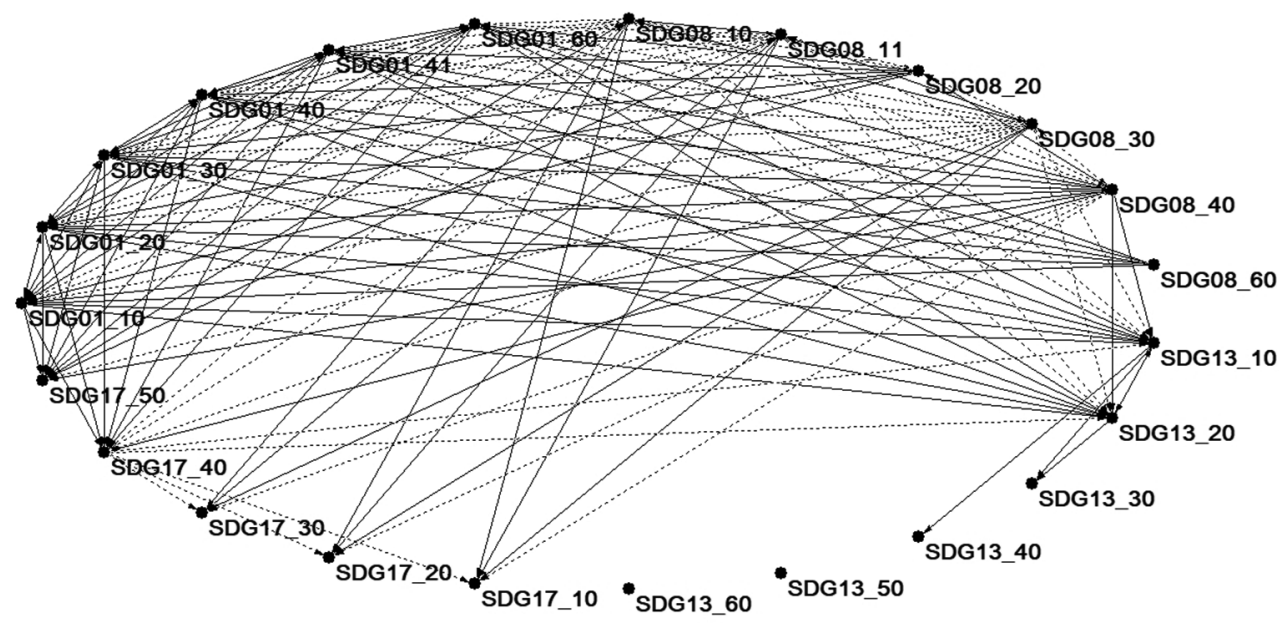

Fig. 4. The final FCM for all goals

Source: own elaboration.

The relationships depicted on all the presented maps can be interpreted as follows:

1. The greatest number of relationships between the indicators within one analysed goal was identified for Goal 1 (Figure 5). This map shows 30 connections between the indicators out of the 36 possible, its density was 0.83 . Additionally, these are positive relationships, meaning that an improvement in one of the indicators positively affects the other with which it is related. The least number of connections was identified in the case of Goal 17 (only 3, density of the map is 0.12) (Figure 6).

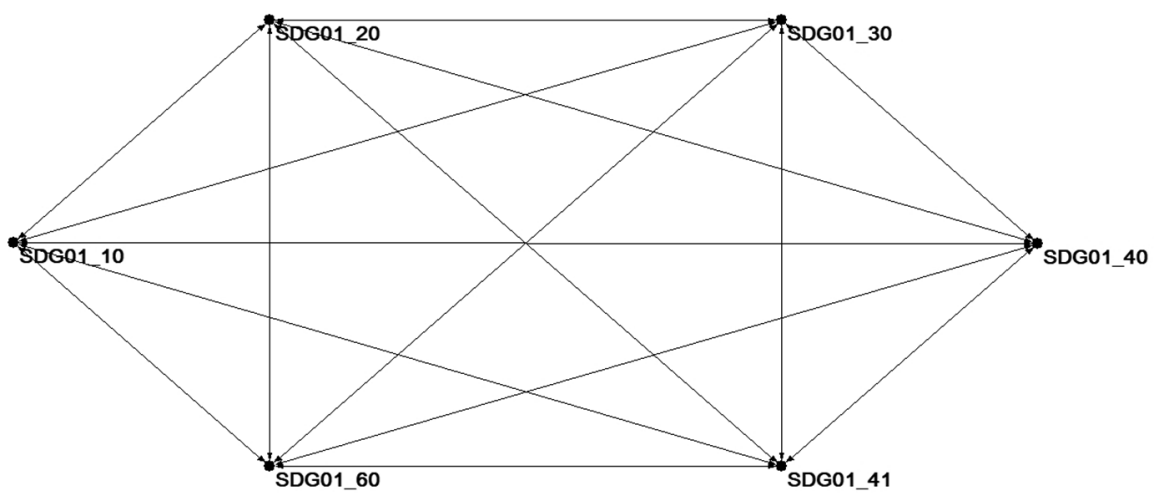

Fig. 5. The final FCM for Goal 1

Source: own elaboration. 


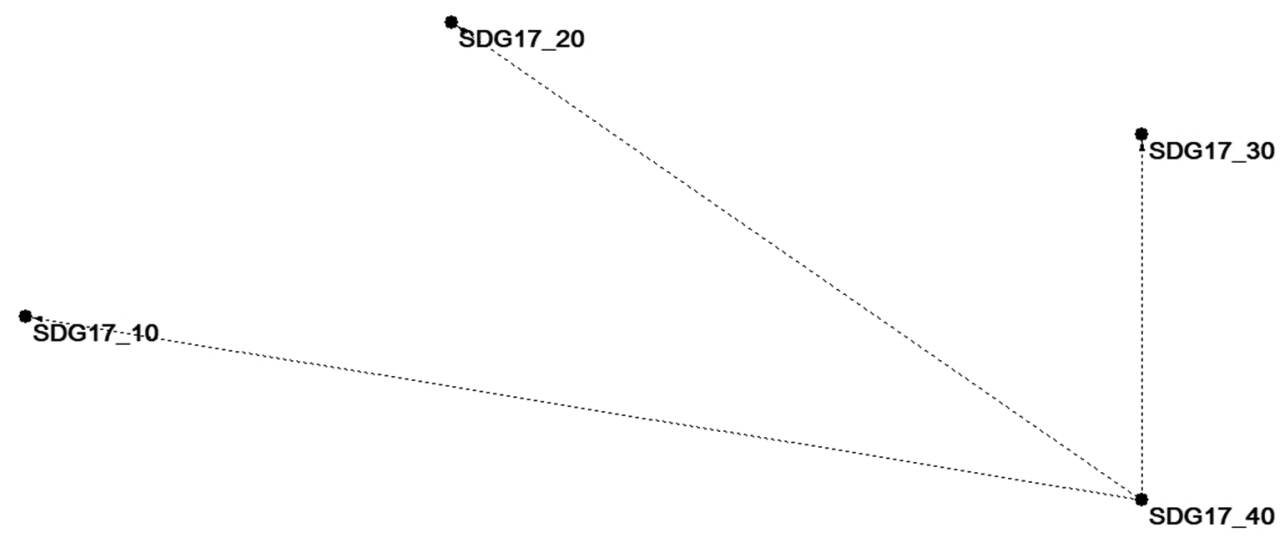

•SDG17_50

Fig. 6. The final FCM for Goal 17

Source: own elaboration.

2. In total, the presented collective map (Figure 4) contains 152 connections, and its density is 0.29 . This means that out of the theoretically possible 529 connections between the analysed criteria, the experts participating in the study indicated approximately $29 \%$. Their complexity can be presented as $5 / 1$, meaning that 5 of the considered variables are receiver and only 1 is transmitter. The most related variables exiting relationships (outdegree) are: SDG08_10, SDG08_11, SDG08_30 and SDG08_40 (they formulate 17 connections). The most related variables entering relationships (indegree) are: SDG13_10 and SDG13_20 (12 connections). The hierarchy index was 0.95 , which means that the map is almost fully hierarchical.

\section{Conclusions}

The purpose of the research, the results of which are presented in this paper, is to identify the relationships between the factors determining the development of the EU economies within the framework of sustainable development. For this purpose, a fuzzy cognitive map (FCM) was used, resulting from the visualization of the opinions of the experts participating in the study. The basis for the selection of the factors of the greatest importance for the target linkage model was the list of selected starting factors used by the European Commission to monitor the progress in the implementation of the latest Sustainable Development Strategy for the EU countries, where 23 indicators describing social development were analysed: Goal 1, No poverty; economic development, Goal 8, Decent work and economic growth; 
environmental development, Goal 13, Climate action, and institutional and political development, Goal 17, Partnerships for the goals.

In accordance with the assumptions of the 2030 Agenda, the individual goals of the strategy should be interrelated. This certainly applies to the goals that can be classified as describing social and economic development, but often also economic and environmental development. However, the research results presented in the paper do not always confirm the existence of the connections between the individual indicators selected for the description of the goals of sustainable development.

While these relations can be observed in the framework of the indicators describing individual goals, there are fewer connections of this type between the indicators describing different goals. It is also worth paying attention to the different possibilities of interpreting the desired directions of changes in the indicators. In this study, this kind of problem concerns, for example, an indicator describing the share of environmental taxes in total tax revenue.

The largest number of relationships between the indicators within one analysed goal was identified in the case of Goal 1 concerning the lack of poverty. These are links meaning that an increase in one indicator will cause an increase in the other with which it is related. It is worth noting that these are mainly indicators describing negative aspects of social development, and a possible increase in these indicators will mean an unfavourable situation (e.g. an increase in poverty). The smallest number of connections was identified in the case of Goal 17, for which only the indicator SDG17_40 (General government gross debt,\% of GDP) was negatively related to three indicators: SDG17_10 (official development assistance as share of gross national income, $\%$ of gross national income), SDG17_20 (EU financing to developing countries by financing source, million EUR (current prices), SDG17_30 (EU imports from developing countries by country income groups, million EUR).

The analysis of the relationships (presented on the maps) of the indicators included in Goal 8 with Goals 1, 13 and 17 and the collective fuzzy cognitive map shows that the number of relationships between the criteria included in the study is significant. Goal 8, describing economic development, is basically the only goal related to all the others analysed in the paper. In this case, some regularities can be noted:

- the indicators included in the economic target in most cases improve the indicators describing Goal 1 (no poverty), this applies to indicators such as: SDG08_10 (real GDP per capita), SDG08_11 (investment share of GDP), and SDG 08 _30 (employment rate,\% of population aged 20 to 64); other indicators in this group (SDG08_20, young people neither in employment nor in education and training; SDG08_40, long-term unemployment rate, and SDG08_60, people killed in accidents at work) negatively affect the implementation of practically all the indicators related to Goal 1;

- only two indicators representing Goal 13 are related to the indicators related to Goal 8, which include: SDG13_10 (greenhouse gas emissions, in $\mathrm{CO}_{2}$ equivalent) 
and SDG13 20 (greenhouse gas emissions intensity of energy consumption, index $2000=100$ ), the values of these indicators according to the experts should decrease as the indicators describing the economic dimension increase;

- there are many, especially positive, links between the indicators describing Goals 8 and 17 ;

- indicator SDG08_60 (people killed in accidents at work, number per 100,000 employees) shows no relation to the indicators representing Goals 13 and 17.

The maps presented in the article are the result of the visualization of the opinions of the experts participating in the study and should not be generalized. The authors realize that the tool used in the form of cognitive maps is not a perfect tool, i.e. a source of unambiguous and always appropriate solutions, but it can constitute the basis for further in-depth research.

\section{References}

Aguilar, J. (2005). A survey about fuzzy cognitive maps papers (Invited Paper). International Journal of Computational Cognition, 3(2), 27-33.

Andreou, A. S., Mateou, N. H., and Zombanakis, G. A. (2003). Evolutionary fuzzy cognitive maps: A hybrid system for crisis management and political decision-making. Conference Proceedings on Computational Intelligence for Modelling Control and Automation, (1), 1-12.

Andreou, A. S., Mateou, N. H., and Zombanakis, G. A. (2005). Soft computing for crisis management and political decision making: The use of genetically evolved fuzzy cognitive maps. Soft Computing Journal, 9(3), 194-210.

Axelrod, R. (1976). Structure of decision: The cognitive maps of political elites. Princeton, New York: Princeton University Press.

Card, D., Kluve, J., and Weber, A. (2010). Active labour market policy evaluations: A metaanalysis. The Economic Journal, (120).

Cole, J. R., and Persichitte, K. A. (2000). Fuzzy cognitive mapping: Applications in education. International Journal of Intelligent Systems, 15, 1-25.

Furfaro, R., Kargel, J. S., Lunine, J. I., Fink, W., and Bishop, M. P. (2010). Identification of cryovolcanism on Titan using fuzzy cognitive maps. Planetary and Space Science Journal, 58(5), 761-779.

Godlewska-Majkowska, H. (2014). Mapa kognitywna jako instrument projektowania zintegrowanego produktu turystycznego gmin. ZS WSH Zarzadzanie, (1), 41-48.

Hage, P., and Harary, F. (1983). Structural models in anthropology. Cambridge: Cambridge University Press.

Isaac, M. E., Dawoe, E., and Sieciechowicz, K. (2009). Assessing local knowledge use in agroforestry management with cognitive maps. Journal of Environmental Management, (43), 1321-1329.

Jastriebow, A., Gad, S., and Słoń, G. (2010). Rozmyte mapy kognitywne w monitorowaniu decyzyjnym obiektów technicznych. Biuletyn WAT, LIX (4), 209-219.

Kannappan, A., Tamilarasi, A., and Papageorgiou, E. I. (2011). Analyzing the performance of fuzzy cognitive maps with non-linear Hebbian learning algorithm in predicting autistic disorder. Experts Systems with Applications, 38(3), 1282-1292.

Kokkinos, K., Lakioti, E., Papageorgiu, E., Moustakas, K., and Karayannis, V. (2018). Fuzzy cognitive map-based modeling of social acceptance to overcome uncertainties in establishing waste biorefinery facilities. Frontiers in Energy Research, 6, 1-17. 
Kosko, B. (1986). Fuzzy cognitive maps. International Journal of Man-Machine Studies, 24(1), 65-75. Lee, S., and Han, I. (2000). Fuzzy cognitive map for the design of EDI controls. Information \& Management, 37(1), 37-50.

MacDonald, N. (1983). Trees and networks in biological models. New York: John Wiley and Sons.

Ozesmi, U., and Ozesmi, S. L. (2004). Ecological models based on people's knowledge: A multi-step fuzzy cognitive mapping approach. Ecological Modelling, 176(1-2), 43-64.

Papageorgiou, E. I. (2012). Learning algorithms for fuzzy cognitive maps - A review study. IEEE Transactions in Systems, Man and Cybernetics - Part C: Applications and Reviews, 42(2) 150-163.

Papageorgiou, E. I., Markinos, A., and Gemtos, T. (2009). Application of fuzzy cognitive maps for cotton yield management in precision farming. Experts Systems with Applications, 36(10), 12399-12413.

Papageorgiou, E. I., Spyridonos, P., Glotsos, D., Stylios, C. D., Groumpos, P. P., and Nikiforidis, G. (2008). Brain tumor characterization using the soft computing technique of fuzzy cognitive maps. Applied Soft Computing Journal, 8, 820-828.

Piotrowska, K. (2011). Zastosowanie map kognitywnych w inteligentnych systemach wspomagania podejmowania decyzji. Logistyka, (6), 3433-3442.

Salmeron, J. L. (2009). Supporting decision makers with fuzzy cognitive maps. Research-Technology Management, 52(3), 53-59.

Skład, A. (2018). Modelowanie systemów zarządzania bhp z wykorzystaniem metody rozmytych map kognitywnych i wskaźników wiodących - ujęcie teoretyczne. Zarządzanie i Ekonomia. Bezpieczeństwo Pracy, (2), 11-15.

Słoń, G., and Yastrebov, A. (2011). Optimization and adaptation of dynamic models of fuzzy relational cognitive maps. In International workshop on rough sets, fuzzy sets, data mining, and granular-soft computing (pp. 95-102), Berlin, Heidelberg: Springer.

Sobczak, A. (2007). Zastosowanie rozmytych map kognitywnych w planowaniu rozwoju zorientowanej na ustugi architektury systemów informatycznych. Retrieved from https://www.researchgate .net/ publication $/ 257891103$

Song, H., Miao, C., Roel, W., Shen, Z., and Catthoor, F. (2010). Implementation of fuzzy cognitive maps based on fuzzy neural networks and application in prediction of time series. IEEE Transactions on Fuzzy Systems, 18(2), 233-250.

Stylios, C., and Groumpos, P. P. (1999). Fuzzy cognitive maps: A model for intelligent supervisory control systems. Computers in Industry, (39), 229-238.

Szopik-Depczyńska, K., Cheba, K., Bąk, I., Stajniak, M., Simboli, A., and Ioppolo, G. (2018). The study of relationship in a hierarchical structure of EU sustainable development indicators. Ecological indicators, 90, 120-131.

Taber, W. R. (1991). Knowledge processing with fuzzy cognitive maps. Experts Systems with Applications, 2(1), 83-87.

Tan, C. O., and Ozesmi, U. (2006). A generic shallow lake ecosystem model based on collective expert knowledge. Hydrobiologia, 563(1), 125-142.

Trzaskalik, T. (2014). Wielokryterialne wspomaganie decyzji. Przegląd metod i zastosowań. Zeszyty Naukowe Politechniki Śląskiej, (74), 239-263.

Wei, Z., Lu, L., and Yanchun, Z. (2008). Using fuzzy cognitive time maps for modeling and evaluating trust dynamics in virtual enterprises. Experts Systems with Applications, 35(4), 1583-1592.

Woźniak, J. (2017). Zarządzanie ryzykiem w przedsiębiorstwach projektowych w sektorach kreatywnych. Część 2: Identyfikacja problemów badawczych - studium przypadku. Zeszyty Naukowe Uniwersytetu Przyrodniczo-Humanistycznego w Siedlcach, (115), Seria: Administracja i Zarzadzanie (42), 85-98.

Zioło, M., Filipiak, M. Z., Bąk, I., and Cheba, K. (2019). How to design more sustainable financial systems: the roles of environmental, social, and governance factors in the decision-making process. Sustainability, 11(20), 1-34. 


\section{ROZMYTE MAPY KOGNITYWNE I ICH ZASTOSOWANIA W NAUKACH EKONOMICZNYCH}

Streszczenie: Głównym celem artykułu jest ekspercka ocena zależności występujących między wybranymi wskaźnikami przeprowadzona za pomocą stosunkowo nowego narzędzia w naukach ekonomicznych - rozmytych map kognitywnych. Efektem zastosowania tego narzędzia jest graficzne przedstawienie zależności między czynnikami zidentyfikowanymi jako kluczowe. W pracy wybrano w tym celu 23 wskaźniki opisujące 4 wybrane cele Strategii na rzecz Zrównoważonego Rozwoju. Agenda 2030. Przyjmuje się, że cele zrównoważonego rozwoju powinny być ze sobą powiązane, ale zdaniem ekspertów dotyczy to tylko niektórych wskaźników. Relacje tego rodzaju można zidentyfikować na pewno w przypadku celów opisujących rozwój społeczny i gospodarczy, często również rozwój gospodarczy i środowiskowy. Przedstawione wyniki badań nie zawsze jednak potwierdzają istnienie połączeń między pojedynczymi wskaźnikami wybranymi do opisu celów zrównoważonego rozwoju. $\mathrm{W}$ artykule podjęto próbę wyjaśnienia tego problemu.

Słowa kluczowe: mapa kognitywna, CM, rozmyte mapy kognitywne, FCM, relacje, graficzna prezentacja. 